\title{
UPAYA MENINGKATKAN HASIL BELAJAR IPA MENGGUNAKAN KOMBINASI MEDIA GRAFIS JENIS BAGAN DAN MEDIA VIDEO
}

\author{
Oleh: Drs. H. Bulkani, M.Pd * dan Edy Franatha**
}

\begin{abstract}
ABSTRAK
Penelitian ini bertujuan untuk: (1) mendeskripsikan peningkatan aktivitas belajar IPA peserta didik pada penggunaan kombinasi media grafis jenis bagan proses dan media video. (2) mendeskripsikan peningkatan hasil belajar IPA peserta didik menggunakan kombinasi media grafis jenis bagan proses dan media video. Subjek penelitian ini adalah peserta didik kelas V SD Negeri 5 Pahandut Palangka Raya. Metode penelitian yang di gunakan adalah penelitian tindakan kelas (PTK). Hasil penelitian menunjukan bahwa (1) ada peningkatan aktivitas belajar peserta didik dengan menggunakan kombinasi media grafis jenis bagan proses dan media video, dan (2) ada peningkatan hasil belajar IPA peserta didik setelah menggunakan kombinasi media grafis jenis bagan proses dan media video, pada siklus I nilai rata-rata yang diperoleh yaitu 75,86 dengan kriteria keberhasilan cukup tercapai dan pada siklus II nilai rata-rata yang diperoleh 93,25 dengan kriteria tingkat keberhasilan pembelajaran sangat tercapai.
\end{abstract}

\section{Kata kunci: hasil belajar IPA dan media grafis jenis bagan dan media video}

\section{PENDAHULUAN}

Penggunaan

media

pembelajaran pada tahap orientasi pembelajaran akan sangat membantu keefektifan proses pembelajaran dan penyampaian pesan dan isi pelajaran pada saat itu.

Selain membangkitkan motivasi dan minat, media pembelajaran juga dapat membantu peserta didik meningkatkan pemahaman, menyajikan data secara menarik, terpercaya, memudahkan penafsiran data dan memadatkan informasi. Media juga dapat mewakili apa yang kurang mampu guru ucapkan melalui kata-kata atau kalimat tertentu. Bahkan keabstrakan bahan dapat dikongkritkan dengan kehadiran media. Dengan demikian peserta didik akan lebih mudah mencari bahan yang akan dipelajari melalui media.

$$
\text { Gagne dan Briggs (Arsyad, }
$$
2007:2) mengatakan bahwa media pembelajaran meliputi alat yang secara fisik digunakan untuk menyampaikan isi materi pengajaran, yang terdiri antara lain buku, taperecorder, kaset, video kamera, video recorder, film, slide (gambar bingkai), foto, gambar, grafik, televisi dan komputer. 
Dengan kata lain, media adalah komponen sumber belajar atau wahana fisik yang mengandung materi intruksional di lingkungan siswa yang dapat merangsang siswa untuk belajar.

Menurut Arsyad (2007:75-76) beberapa kriteria dalam memilih media pengajaran yaitu sesuai dengan tujuan yang ingin dicapai, Tepat untuk mendukung isi pelajaran yang sifatnya fakta, konsep, prinsip, atau generalisasi, Praktis, luwes dan bertahan, Guru terampil menggunakannya, Pengelompokan sasaran dan Mutu teknis.

Pembelajaran IPA lebih menekankan kepada pemberian pengalaman secara langsung. Untuk itu pembelajaran dengan menggunakan media, khususnya media grafis termasuk media visual dikombinasikan dengan media video.

Jennah (2009:56): "Jenis-jenis media grafis yang dapat digunakan dalam proses pembelajaran antara lain bagan, grafik, diagram, gambar, poster, peta, kartun, surat kabar atau majalah dan buku". Sedangkan menurut Menurut Sadiman (2007:28) mennyatakan media grafis termasuk media visual. Sebagaimana halnya media yang lain media grafis juga berfungsi untuk menyalurkan pesan dari sumber ke penerima pesan.

Munadi

menyatakan Video adalah sarana menyimpan dan mencari kembali gambar. Video sebagai salah satu media audio visual dijadikan sebagai salah satu alternatif untuk pembelajaran IPA sehingga menjadikan penyajian bahan ajar semakin lengkap dan optimal diharapkan peserta didik lebih paham akan materi pembelajaran yang akan dipelajari sehingga aktivitas dan hasil belajar peserta didik meningkat.

Berdasarkan hasil observasi di kelas V SD Negeri 5 Pahandut Palangka Raya, dalam proses pembelajaran IPA di kelas V, ternyata hasil belajar IPA rendah dikarenakan oleh beberapa faktor diantaranya, Pembelajaran IPA dilakukan dengan metode yang kurang bervariasi dan sederhana sehingga tidak dapat dipahami oleh peserta didik, rendahnya minat peserta didik dalam proses pembelajaran IPA peserta didik lebih asyik dengan kegiatan mereka masing-masing ada yang menggambar, ada yang mencoretcoret buku tulis dan ada yang bermain sendiri.

Tidak adanya respon balik peserta didik dalam proses pembelajaran dan kegiatan pembelajaran menyebabkan peserta didik menjadi tidak aktif dalam proses pembelajaran IPA. Selain itu, guru terlihat jarang menggunakan media saat kegiatan pembelajaran khususnya pada pelajaran IPA peserta didik kelas V SD Negeri 5 Pahandut Palangka Raya.

Pernyataan ini didukung dari kenyataan bahwa hasil belajar IPA pada kelas V SDN-5 Pahandut 
Palangka Raya hanya 39,1 \% (9 orang peserta didik) yang mendapat nilai lebih dari KKM, sedangkan $60,9 \%$ (14 orang peserta didik) mendapat nilai kurang dari KKM yang sudah ditentukan oleh kurikulum sekolah untuk pembelajaran IPA yaitu mencapai nilai 70, sedangkan ketuntasan klasikal proses pembelajaran yang telah di tetapkan oleh kurikulum pemerintah yaitu $85 \%$ dan dari data observasi terhadap minat belajar, minat belajar peserta didik sebesar $69,6 \%$ atau 16 orang peserta didik minat belajarnya rendah, hanya 30,4 $\%$ atau 7 orang peserta didik yang minat belajarnya tinggi.

Berdasarkan uraian di atas mendorong peneliti untuk membantu guru dalam pembelajaran IPA di SD Negeri 5 Pahandut tersebut menerapkan strategi pembelajaran dengan menggunakan kombinasi media grafis jenis bagan proses dan media video yang menggunakan VCD di tampilkan melalui LCD dapat dijadikan sebagai salah satu alternatif untuk pembelajaran IPA.

Dengan demikian peneliti tertarik melakukan penelitian tindakan kelas dengan judul "Upaya Meningkatkan Hasil Belajar IPA Menggunakan kombinasi Media Grafis Jenis Bagan dan Media Video. Penelitian akan dilaksanakan pada kelas V SD Negeri 5 Pahandut Palangka Raya Tahun Pelajaran 2014/2015".
Tujuan penelitian ini yaitu: Untuk mengetahui aktivitas belajar IPA peserta didik pada penggunaan kombinasi media grafis jenis bagan proses dan media video menggunakan VCD materi daur air dan Untuk mengetahui peningkatan hasil belajar IPA peserta didik setelah menggunakan kombinasi media grafis jenis bagan proses dan media video menggunakan VCD materi daur air.

\section{METODE PENELITIAN}

Jenis penelitian yang digunakan adalah penelitian tindakan kelas atau yang lebih akrab didengar yaitu PTK. Kunandar (2010:44-45) PTK didefinisikan sebagai suatu penelitian tindakan (action research) yang dilakukan oleh guru yang sekaligus sebagai peneliti di kelasnya atau bersama-sama dengan orang lain (kolaborasi) dengan jalan merancang, melaksanakan dan merefleksikan tindakan secara kolaborasi dan parsitipatif yang bertujuan untuk memperbaiki atau meningkatkan mutu (kualitas) proses pembelajaran di kelasnya melalui suatu tindakan (treatment) tertentu dalam suatu siklus.

Subjek penelitianya adalah peserta didik kelas V SD Negeri 5 pahandut sebanyak 23 orang peserta didik. Mengumpulkan data dalam penelitian ini digunakan teknik observasi dan tes. Teknik analisis data yang digunakan adalah kualitatif dan kuantitatif. Data kualitatif 
berasal dari hasil observasi yang dideskripsikan dan data kuantiatif sebagai hasil dari pretest dan postest yang dilakukan.

\section{HASIL DAN PEMBAHASAN}

Hasil penelitian ini berdasarkan hasil pengamatan terhadap aktivitas peserta didik dalam pelajaran IPA dilihat dari lembar observasi pada siklus I skor rata-rata yang diperoleh peserta didik adalah 27 dengan kriteria baik.

Pada siklus I ini, ada 9 orang peserta didik yang perlu mendapat perhatian khusus agar aktivitas peserta didik dalam pembelajaran IPA dengan menggunakan media grafis jenis bagan proses dan media video menggunakan VCD agar lebih aktif. Dalam proses pembelajaran 9 orang peserta didik ini rata-rata tidak memperhatikan guru waktu menjelaskan materi pembelajaran, asyik dengan kegiatannya sendiri dan bermain dengan teman sebangku.

Sedangkan pada siklus II, 9 orang peserta didik yang mendapat perhatian khusus pada siklus I sudah menjadi lebih baik hal ini dapat dilihat dari skor rata-rata yang diperoleh peserta didik adalah 38 dengan kriteria sangat baik. Hasil belajar peserta didik setelah menggunakan kombinasi media grafis jenis bagan proses dan media video mengalami peningkatan. Hasil penelitian ini menunjukan bahwa dapat diketahui hasil belajar dan perolehan nilai peserta didik dari pre test sampai post test siklus II telah mengalami peningkatan, pada pre test persentase ketuntasan klasikalnya hanya mencapai $47,82 \%$ dengan kategori kurang tercapai, rata-rata perolehan nilai adalah 64,13 yaitu dari 23 orang peserta didik hanya ada 11 orang peserta didik yang tuntas memperoleh nilai di atas KKM, sedangkan 12 orang peserta didik belum mencapai nilai KKM yaitu 70 .

Hasil belajar pada siklus I cukup mencapai indikator penelitian yaitu persentase ketuntasan klasikal mencapai $69,56 \%$ dengan kategori cukup tercapai, rata-rata perolehan nilai adalah 75,86 yaitu dari 23 orang peserta didik ada 16 orang peserta didik yang sudah memperoleh nilai di atas KKM, dan ada 7 orang peserta didik yang belum mencapai nilai ketuntasan KKM.

Peningkatan ini sudah dapat dikategorikan cukup tercapai, akan tetapi belum dapat dikatakan tuntas secara keseluruhan dan diperlukan suatu upaya kearah peningkatan hasil belajar tuntas secara keseluruhan siklus II.

Hasil belajar pada siklus II hasil post test menunjukan bahwa dari 23 orang peserta didik telah memperoleh nilai lebih di atas KKM dan tuntas secara keseluruhan yaitu berdasarkan hasil refleksi pada siklus II. 
Dari 23 orang peserta didik ada 14 orang peserta didik yang memperoleh nilai 91-100, dari 23 orang peserta didik ada 9 orang peserta didik yang memperoleh nilai 80-90.

Dari 23 peserta didik tersebut ada 3 nama yang peneliti jadikan sampel dari peningkatan hasil belajar yang telah dicapai yaitu pertama kode peserta didik A dilihat berdasarkan data dari nilai tes pra tindakan nilai yang diperoleh 60, sedangkan pada siklus I nilai yang diperoleh meningkat 10 poin menjadi 70 dan pada siklus II nilainya adalah 95.

Kedua yaitu kode peserta didik P.A dilihat berdasarkan data dari nilai tes pra tindakan nilai yang diperoleh 60, sedangkan pada siklus I nilai yang diperoleh meningkat 10 poin menjadi 70 dan pada siklus II nilainya adalah 85 .

Ketiga yaitu kode peserta didik T.N.A dilihat berdasarkan data dari nilai tes pra tindakan nilai yang diperoleh 65, sedangkan pada siklus I nilai yang diperoleh meningkat 15 poin menjadi 75 dan pada siklus II nilainya adalah 90 .

Hal ini membuktikan bahwa ketuntasan klasikal pada siklus II lebih meningkat hingga $100 \%$ dengan kategori sangat tercapai yaitu rata-rata perolehan nilai 93,26 yang artinya sudah sangat mencapai indikator ketercapaian yang telah ditetapkan yaitu $85 \%$.

\section{KESIMPULAN}

Berdasarkan hasil penelitian dapat disimpulkan beberapa hal yaitu sebagai berikut:

1. Aktivitas peserta didik dengan menggunakan kombinasi media grafis jenis bagan proses dan media video lebih aktif disetiap siklus.

2. Ada peningkatan hasil belajar IPA peserta didik setelah menggunakan kombinasi media grafis jenis bagan proses dan media video. Sebelum melaksanakan penelitian tindakan kelas

\section{DAFTAR PUSTAKA}

Arsyad, Azhar. 2007. Media Pembelajaran. Jakarta: PT Raja Grafindo Persada.

Jennah, Rodhatul. 2009. Media Pembelajaran. Banjarmasin: Antasari Press.

Kunandar. 2010. Langkah Mudah Penelitian Tindakan Kelas Sebagai Pengembanagan Propesi Guru. Jakarta: PT. Raja Grifindo Persada.

Munadi, Yudhi. 2013. Media Pembelajaran. Jakarta: GP Press Group.

Sadiman, Arief S. dkk. 2007. Media Pendidikan. Jakarta: PT Raja Grafindo Persada. 